Pavel Zdražil ${ }^{1}$, Bohuslav Pernica²

\title{
Stimuli contributing to local property taxation - with the focus on spatial effects of industry and functional urban areas
}

\begin{abstract}
In this study, we argue that a historical background of the region matters in tax mimicking and yardstick competition as a matter of principle. We seek to determine factors supporting the policy of the high local property tax in the Czech Republic. Based on the statistical and spatial data of 6,258 municipalities between 2009 and 2019, the results show that the municipalities burdened by large industrial facilities, as well as municipalities in the functional urban areas (FUAs), apply the policy of higher property taxation twice frequently than the rest. On the other hand, the industrial stimuli keep enfeebling after 2010, and the number of local governments preferring high property taxation is variegated across different FUAs. The causal analysis based on Granger's approach concludes an existence of cumulative effects of both industry and the FUAs, which push the municipalities with large industrial facilities located within an FUA to increase the property taxes. From the mimicking point of view, we found that mimicking policy is an important phenomenon among the municipalities of Czech Republic; however, it has different impacts on both stimuli (Industry and FUA). The analysis suggests that it rather incites the municipalities within the FUA to increase the local property taxes.
\end{abstract}

KEYWORDS: Czech Republic, functional urban area (FUA), industry, property tax, local government, tax mimicking

JEL CLASSIFICATION: H71, O18

RECEIVED 20 May 2020; ACCEPTED 20 January 2021.

\section{INTRODUCTION}

In response to the fiscal stress, which started as the consequence of the 2008 financial crisis, the Czech municipalities were authorised to determine a portion of their revenue. Since 2008, the local governments have opted for a multiple of the local property tax coefficient, a number varying from 1 to 5 and affecting the tax base, in order to win more property tax revenue (Sedmihradská and Bakoš 2016). This tax was the only one in which revenue from has not been shared with the central government. Thus, empowerment of municipalities by the power of determination of this tax revenue could bring extra revenues, slowing down the municipal debt. In fact, when the stress dissipated, municipalities received a critical instrument for local development, affecting both the discretion of elected officials and participation of citizens (Sokolow 1998). So, a deal of municipalities keeps applying the policy of the high local property tax coefficient. Because of this, the tax innovation within the model of fiscal federalism was not been intended as an instrument contributing to local development; any sticking to this kind policy implies the question what factors might contribute to such as a conduct eventually. Might it be an immanent part of the local government's planes or is it just the mimicking phenomenon when local governments copy each from other? Possibly, the decision on tax rising is just based on the ability to pay because there is an exceptional concertation of wellsituated taxpayers, such as various industry facilities - as a result of the development in the last 150 years, who are not able to leave the territory where a higher property tax was levied? What is the significant nexus within the local governments that made their decisions on continuing the policy of the high property tax coefficient? In order to answer such research questions, the aim of this paper is to determine factors contributing to the continuation of the policy of the high local property tax coefficient in the Czech Republic.

1 Faculty of Economics and Administration, University of Pardubice, email: pavel.zdrazil@upce.cz

2 Faculty of Economics and Administration, University of Pardubice 
The paper is organised as follows: the literature review, which introduces the problem by discussing the tax policy at local level, continues to argumentation for setting of two research hypotheses. The next section describes the methodology for the empirical analysis and data. The following section discusses the results, and the last section concludes the paper.

\section{STATEMENT OF THE PROBLEM}

\section{The literature review}

A lot of scholars dealing with the issues of tax policy at the level of local governments often pay a close attention to tax mimicking phenomenon, a situation when neighbouring local governments follow the same pattern of tax policy in order to support another kind of their public policy. For instance, the tax mimicking is a part of yardstick competition, as presented by Besley and Case (1995) for the United States on data covering the period 1960-1989, Bordignon et al. (2003) for Italy, Allers and Elhorst (2005) for the Netherlands, Revelli and Tovmo (2007) for Norway, Baskaran (2014) for the German State of North Rhine-Westphalia, Bastida et al. (2019) for Spain, Małkowska et al. (2018) for Poland and Sedmihradská (2013) for the Czech Republic.

Scholars focusing on the public policy might pay a closer attention to dynamics of agenda-settings. Local tax policy as a part of yardstick competition might be considered as an innovation in public policy that has a potential to diffuse within a specific region (Bordignon et al. 2004). It is an evolutionary process when local governments are changing their policy. Thus, the policy of the high local property tax coefficient might be analysed from the point of view Baumgartner and Jones' punctuated equilibrium model, as John (1999) did it for British local government finance in the early 1990s.

Scholars in social sciences pay a closer attention to ideological motivation of tax competition among the local governments, e.g. Solé Ollé (2003), or they focus on intergovernmental and inter-regional relationship within a framework of fiscal federalism, e.g. Fossen et al. (2017), Buettner and von Schwerin (2016), Gerard et al. (2010) and Bordington et al. (2004). Other scholars focus on an impact of yardstick competition on local prices; for instance, Klien (2015) who scrutinised the impact of tax policy on water prices in Austria.

Rarely, the issue of local tax policy and tax mimicking is analysed in a nexus with other factors contributing to local governments' decision-making on taxation as presented by Goemine and Smolders (2015). Nevertheless, the question what factors matter in local tax policy is a momentous one. For instance, analysing the panel data set of 104 French local governments from 1989 to 2001, Dubois and Paty (2010) found that "voters reward their incumbent when neighbouring cities that are similar in terms of demographic characteristics have high local taxes". Also, a level of concentration of population in an analysed region where policy of high local taxes is applied matters in local political decision-making.

As noted by Zdražil and Pernica (2018), there were a lot of municipalities in the Czech Republic that raised the local property tax coefficient whenever their region was affected by a presence of some booming industry. For instance, a number of municipalities in well-visited mountain resorts and municipalities with a significant presence of automotive or power industry opted for the policy of the high local property tax coefficient. Furthermore, Zdražil and Pernica (2018) pointed out that the policy of high local coefficient (LC) is frequently applied in areas positioned close to large cities coping with the burden of sub-urbanisation. For instance, Schneider (1987) explains the taxation in sub-urban zones as an effect of inequalities between the taxes collected, which spreads the pressure on raising the local tax bases.

\section{The hypotheses}

So, it seems that the policy of higher property taxation, known in the Czech Republic as the policy of the high local property tax coefficient, and systematically applying by ca $10 \%$ of municipalities since 2008 is linked mostly with demographic and economic booming areas. In other words, the municipalities take advantage of economic development to maximise their tax revenue, although they have not contributed to decision of private actors to install their property in the municipality. From this point of view, the policy of higher property taxation is hardly to interpret as a yardstick competition, since the effects of this policy, e.g., described in an econometric model by Bastida et al (2019), remains statistically insignificant. 
Following those arguments, the municipal decision-making on local taxation should be analysed in the nexus with some spatial pattern of the region because the higher local property tax has been often levied on the real estate, which had been generated as a consequence of regional development in the past. Yet, that is not in accord with theory of yardstick competition because investors allured in the municipality in the past are penalised finally by higher taxation on their property. In that opinion, we assume that the propensity of municipalities to raising the local property tax coefficient in particular regions is more than just a tax mimicking and yardstick competition, as presented by Sedmihradská and Bakoš (2016). Due to the fact that a significant number of municipalities keep continuing the policy of the high local property tax coefficient after the fiscal stress as presented in the Tab. 1, there may be more links between the policy of the high local property tax coefficient and the socioeconomic background of the region where the coefficient was raised.

Tab. 1: The response to the fiscal stress by the municipalities in the Czech Republic, 2008-2018

\begin{tabular}{|c|c|c|c|c|c|c|c|c|c|c|c|}
\hline & 2008 & 2009 & 2010 & 2011 & 2012 & 2013 & 2014 & 2015 & 2016 & 2017 & 2018 \\
\hline Revenue, CZK bn & 269.2 & 261.3 & 283.6 & 268.6 & 241.1 & 256.2 & 272.9 & 279.5 & 279.0 & 294.2 & 330.9 \\
\hline Expenditure, CZK bn & 253.6 & 279.4 & 287.0 & 269.8 & 235.1 & 238.7 & 263.9 & 257.6 & $239 \cdot 3$ & 272.8 & 322.6 \\
\hline Debt, CZK bn & 80.1 & 80.6 & 83.3 & 82.4 & 90.0 & 92.2 & 88.9 & 86.9 & 71.9 & 69.0 & 68.6 \\
\hline $\begin{array}{l}\text { Property tax revenues of municipalities, CZK } \\
\text { bn }\end{array}$ & 5.1 & 6.3 & 8.7 & 8.6 & 9.6 & 9.7 & 10.0 & 10.3 & 10.6 & 10.8 & 10.9 \\
\hline Property tax as a \% of municipalities revenue & 1.9 & 2.4 & 3.1 & 3.2 & 4.0 & 3.8 & $3 \cdot 7$ & $3 \cdot 7$ & 3.8 & $3 \cdot 7$ & $3 \cdot 3$ \\
\hline $\begin{array}{l}\text { Property tax as a } \% \text { of revenue of } \\
\text { municipalities with } L C>1\end{array}$ & - & 5.0 & 6.2 & 6.4 & 6.2 & 6.1 & 6.1 & 6.0 & 6.0 & 6.1 & 6.2 \\
\hline
\end{tabular}

$L C=$ local coefficient; $C Z K=$ Czech national currency

Source: own calculations based on MFCR (2020)

As presented in the Tab. 1, the municipalities faced a fiscal stress by 2013. In response to a significant drop in revenues, the debt of municipalities was increasing. In order to cover this drop, some municipalities took advantage of policy of the high local property tax coefficient. Property tax revenues doubled between 2008 and 2014, and this tax gained more significance in local budgets. Taking into account just municipalities with the LC 2, 3, 4 or 5, the significance of property tax in their budgets is almost twofold in comparison with other municipalities.

However, the local property tax is levied on the housing development and industry and the level of socioeconomic developed of a region encourages the local governments to tax the population and industry concentrating in the municipality with high property tax. From that point of view, the tax mimicking may be just a spin-off of regional development and spatial distribution of the industry and population in the past. As presented by Zdražil and Pernica (2018), there is a link between the level of standard of living in a municipality and the level of property tax coefficient set by the local government, that is, municipalities applying the policy of the high local property tax coefficient kept the standard of living determined as a combination of population indicators and availability of public services, such as education and medical facilities, communication services, fire brigades, etc. Yet, other municipalities maintain the same standard of living without any need of extra revenues. Therefore, the option for a higher taxation might be determined by an extra factor standing still out of scholars' attention.

Due to the fact that tiny municipalities, such as Trnavka, Vresova and Nizni Lhoty, opted for the highest LC when a large industry facility, such as a power plant, was operated on their administrative territory, we supposed that a localisation of industry in the municipality inspires the local government to impose a higher taxation on it. In particular, when industry is suspected to produce negative externalities, such as pollution. However, this taxation cannot be considered as a Pigovian tax, because the same decision on higher property taxation was made also by municipalities without any significant location of dirty industry.

On the other hand, densely populated municipalities, such as large cities with a status of regional centres, opted frequently for the policy of higher taxation as well. By 2020, 15 of 26 of such municipalities opted for a rising of the LC; 11 of them continue this policy for more than nine fiscal years. Nonetheless, the regional centres usually opted for the LC 2, that is, lower tax increase per 
unit. In comparison with municipalities with the localisation of industrial facilities, they utilise concertation of population in order to maximise tax revenue on the low level of the LC.

It means that decision-making on raising of the $\mathrm{LC}$ is supposed be motivated by those two patterns of thinking. In order to test an impact of socioeconomic background of the region on the decision-making of local governments on an introduction and continuing of the policy of the high local property tax coefficient, two hypotheses were set:

H1: The localisation of industry stimulates municipalities to increase the local property tax.

$\mathrm{H} 2$ : The concentration of population and economic activity stimulates municipalities to increase the local property tax.

\section{METHODS AND DATA}

To fulfil the aim of this paper, the analysis is based on the following methods and assumptions. It covers the period of 2009-2019. The statistical data for computation were obtained from the Ministry of Finance of the Czech Republic (MFCR). Those inputs were partly acquired on demand (the list of municipalities applying the high local property tax coefficients in a particular fiscal year), partly from the public information portal Monitor (MFCR 2020).

From the spatial point of view, the analysis covers all municipalities in the Czech Republic, that is, there are 6,258 municipalities taken into account. The spatial computations were performed with QGIS 3.8 (2019). The spatial data about industry were linked from the CORINE land cover inventory, a European land monitoring service (Copernicus Programme 2020). This source provided valuable data needed for a compilation of the large-sized industrial facilities, that is, facilities being located at least on 25 hectares. However, we should point out that the objects of the higher taxation are not only industrial once, but also commercial and transportation units, mines, dumps and construction sites are taxed. Besides, sport and leisure time facilities are liable to higher local taxation, indeed. Hence, all the mentioned objects are considered to be "large industrial facilities" in this research.

The concentration of population and economic activity are operationalised in accordance with the OECD-EU approach as functional urban areas of large cities (FUA) "FUA consists of a densely inhabited city and of a surrounding area (commuting zone) whose labour market is highly integrated with the city" (OECD 2012). From that point of view, the cities are taken into account as the most significant drivers of social and economic activity in a specific region. Their presence in the specific area is usually beneficial to other municipalities in their vicinity. Such municipalities often benefit on activities organised by large cities. For instance, the small villages in the vicinity of a city can take advantage of using of commuting zones within an FUA that is organised by the large city. Hence, the analysis of FUA is weighty for tracking any impacts of large cities on their neighbourhood. The list of municipalities in national FUAs was taken from the OECD portal (OECD 2020).

Being familiar with the tax mimicking phenomenon in national economies by the literature review, we made a decision to measure the intensity of tax mimicking. Defining a "mimicking coefficient" (MC), we sought to track the development of the tax mimicking phenomenon in order to access its impacts on the results. Hence, we developed the coefficient as a ratio (1). This MC allow us to estimate the share of municipalities in which one can consider the impact of mimicking practices.

\footnotetext{
a number of municipalities applying the high local coefficient policy, which neighbours

$M C=\frac{\text { with at least one other municipality, also applying the high local coefficient policy }}{\text { the number of municipalities in total }}$
}

Finally, we employed the econometrical causal analysis proposed by Granger $(1969 ; 1988)$ in order to determine the statistical significance of all stimuli under examination. We paid a closer attention to a link between the indication of tax mimicking and a presence of large industrial facilities, as well as to a link between FUAs and tax mimicking. Due to the fact that the Granger causality testing requires stationary volumes, we performed the augmented Dickey-Fuller unit root test (Dickey and Fuller 1979; Said and Dickey 1984). This test verifies all the volumes are non-stationary in a level. Moreover, the test also found the volumes to be stationary after their transformation to the level of second differences; hence, we proceeded such a transformation. In addition, the most suitable lag lengths were determined by using Akaike's test (Akaike 1974). At last, we only summarise that we used the conventional settings of the methods above. These are set as a default option in Gretl 2019c (2019), which was used for computations. 


\section{PROBLEM-SOLVING AND DISCUSSION}

Tab. 2 presents the spread of the policy of higher local property taxation because the local governments were authorised to raise the LC. Yet, assessing the dynamics, the period is to be divided into two sub-periods. A milestone is the end of 2014 when fiscal stress died down and local governments might feel free to cut down the taxation. Prior to 2014, the policy of higher local property tax coefficient was implemented by between 4.5 and $8.3 \%$ of municipalities. Nonetheless, there were a substantial number of municipalities too that decided to abandon this policy prior to 2014. In total, there were 694 local governments in the Czech Republic (11.1\%) that decided to raise the local property tax coefficient between 2009 and 2014. However, only 518 municipalities kept sticking to the policy of higher local property taxation in 2014, while 176 municipalities applied and finally resigned on this policy by 2014 .

In comparison, the share of local governments opting for higher local property taxation increased from 8.3 to $9.6 \%$ beyond 2014. In the same time, only 10 municipalities abandoned the policy. The measurement of stability expressed by the coefficient of variation over time shows a drift of $22.1 \%$ prior to 2014 . After 2014 , this indicator dropped to $6.0 \%$.

Tab. 2: Application of higher local coefficient in 2009-2019

\begin{tabular}{llllllllllll}
\hline & $\mathbf{2 0 0 9}$ & $\mathbf{2 0 1 0}$ & $\mathbf{2 0 1 1}$ & $\mathbf{2 0 1 2}$ & $\mathbf{2 0 1 3}$ & $\mathbf{2 0 1 4}$ & $\mathbf{2 0 1 5}$ & $\mathbf{2 0 1 6}$ & $\mathbf{2 0 1 7}$ & $\mathbf{2 0 1 8}$ & $\mathbf{2 0 1 9}$ \\
\hline Mun. LC & 389 & 284 & 299 & 404 & 494 & 518 & 522 & 562 & 588 & 598 & 599 \\
\hline Mun. LC (\% of all) & 6.2 & 4.5 & 4.8 & 6.5 & 7.9 & 8.3 & 8.3 & 9.0 & 9.4 & 9.6 & 9.6 \\
\hline MC (\% of mun. LC) & 59.1 & 54.2 & 57.5 & 62.4 & 68.0 & 70.3 & 70.9 & 72.6 & 73.5 & 73.4 & 73.1 \\
\hline
\end{tabular}

Mun. LC = municipalities that applied higher local coefficient of property tax;

$M C=$ mimicking coefficient

Source: own calculations

Taking into account the dynamics of dissemination of the policy of the higher local property coefficient within the Czech Republic, we can assume that local governments learnt about potentials and limitations of this policy during 2009-2014. After 2014, a saturation point is to be observed when the application trend of LC is more stable afterwards.

Also the tax mimicking hypothesis gained its significance, as the spatial analysis identified that a majority of the municipalities, which applied higher LC, have at least one common border with at least one municipality in its direct neighbourhood that opted for the policy of higher local property tax coefficient as well. In general, the MC increased from 59 up to $73 \%$ during the period of 2009-2019; in addition, the dynamics of changes has decreased after 2014. Basing on these facts, we can consider that the local governments established "spatial clubs". The membership in such a "clubs" is derived from common approaches to the policy of higher property taxation. The size of a "club" is determined by local governments' preferences to adapt the policy of their neighbours. In fact, most clubs are growing in their size. This point is crucial for the examination of a possible impact of large industrial facilities and FUAs on the decision-making on a raise of the local property tax coefficient, as the mimicking behaviour proceeds.

\section{The impact of large industrial facilities}

Following the aim of this paper, the links between localisation of large industrial facilities and the LC of property is examined in this part. As presented in the Tab. 3, there are 1,713 large industrial facilities that are distributed across 1,442 municipalities, that is, at least one large industrial facility is localised in $23 \%$ of Czech municipalities. However, as presented in the Tab. 3, the large industrial facilities are localised in one-half of municipalities that apply the policy of the higher local property tax coefficient. Therefore, the municipalities burdened by large industrial facilities apply the policy of higher property taxation twice frequently than the rest. 
Tab. 3: Municipalities with large industrial facilities that apply the policy of higher local coefficient in 2009-2019

\begin{tabular}{llllllllllll}
\hline & 2009 & 2010 & 2011 & 2012 & 2013 & 2014 & 2015 & 2016 & 2017 & 2018 & 2019 \\
\hline Ind. mun. LC & 191 & 147 & 154 & 204 & 236 & 248 & 248 & 268 & 276 & 279 & 279 \\
\hline $\begin{array}{l}\text { Ind. mun. LC (\% of } \\
\text { mun. LC) }\end{array}$ & 49.1 & 51.8 & 51.5 & 50.5 & 47.8 & 47.9 & 47.5 & 47.7 & 46.9 & 46.7 & 46.6 \\
\hline
\end{tabular}

Ind. mun. $L C=$ municipalities applying higher local coefficient of property tax that have large industrial facility in their area of administration Source: own calculations

As presented in the Tab. 3, the importance of the industry factor is decreasing over time when the peak was in 2010 and the bottom in 2019. Based on the figures above, the presence of the industry should be considered as an inducement for an implementation of the policy of higher local property coefficient during the acute fiscal stress. In particular, it was an easy way how to get extra tax revenue when national economy slowed down due to the financial crises of 2008.

Yet, the stress subsided and other stimuli for taxation of real estate emerged. The policy became inviting to municipalities with a different background. With regard to the development after 2010, the industrial stimuli keep enfeebling although tax mimicking keeps on. In fact, the large industry is localised irregularly in the Czech Republic. The municipalities with its presence in their administrative territories opted for its higher taxation as the first once; however, as mimicking proceeds, than increasing number the policy appliers attract not only municipalities with industrial facilities to join, but also that with a different spatial background.

Going more into detail, we found out that property tax did become significant for some local governments. For instance, property tax is a substitutional source of revenues in the budget of the municipality of Temelin, where a nuclear power plant is installed. According to MFCR (2020), the increased portion of property tax revenues amounted 40\% of all budget revenues in 2018. Trnavka, a village of 229 residents, in the close vicinity of the private coal power plant Chvaletice, won $50 \%$ of the budget revenues as the increased portion of property tax revenues in 2018 (MFCR 2020). Besides, 25 local governments sticking to the policy of higher (highest) local property tax coefficient in 2018 gain $15 \%$ of their revenues as the increased portion of property tax once. As presented in the Tab. 4, those municipalities have to bear the presence of different industries.

Tab. 4: Industry in municipalities with the highest share of increased total revenue due to the increased local coefficient

\begin{tabular}{llllll}
\hline Municipality & Industry & Municipality & Industry & Municipality & Industry \\
\hline Dukovany & Nuclear PP & Libis & CP & Stonava & Mining \\
\hline Rouchovany & Nuclear PP & Zaben & CP, electrical substation & Dolni Nivy & Quarry \\
\hline Temelin & Nuclear PP & Sivice & Cement plant, PPP & Vrskman & Quarry \\
\hline Trnavka & Coal PP & Bitozeves & Industrial zone & Stare Hamry & Ski resort \\
\hline Vresova & Steam-gas PP & Velemysleves & Industrial zone & Bila & Ski resort \\
\hline Nizni Lhoty & MP, PPP & Uzice & Industrial zone & Vlkancice & Recreation area \\
\hline Chrastany & MP, PPP & Modletice & Shopping zone & & Fusoka \\
\hline Nosovice & MP & Otvice & Shopping zone & & Fuel store \\
\hline Paskov & CP & Cestlice & Shopping zone & &
\end{tabular}

$P P=$ power plant; $P P P=$ photovoltaic power plant $C P=$ Chemical plant;

$M P=$ Machinery plant

Source: own processing 
On the other hand, the property tax is levied not only on industrial sector, but households are taxed as well. That shows the local governments in a bad light. Yet, the local governments are usually conscious of these consequences. In order to respond to any taxpayers' criticism, they established munificent programmes of subsidises. For instance, both Trnavka and Temelin provide a special programme supporting just their residents (Latislav 2020; Otta 2009). Was it really an aim to authorise the local governments to build up a few of micro imperio in imperium that are independent from the distribution of tax revenues by central rules of fiscal federalism in fact? However, this analysis has explained just a part of local governments' motivation to implement a local policy of high property taxation.

\section{The impact of FUAs}

Another part of the expected stimuli for increased property taxation is the uneven concertation of population on the state territory. Also, we should analyse the spatial distribution of municipalities that apply the LC as the next step. The reason is to examine the supposed link between the application of LCs and densely inhabited cities with their commuting zones, that is, within FUAs.

Following the OECD definition (2012), there are 1,745 municipalities belonging to FUAs in the Czech Republic. That means there are almost $28 \%$ of municipalities that are highly integrated with their regional centres in terms of commuting. As Tab. 5 shows, the share of municipalities applying the policy of the higher property taxation within an FUA is slightly below 50\%. As the municipalities in the presence of large industrial facilities alike, the municipalities in FUAs apply the policy of higher local property tax coefficient twice frequently than the rest. Nonetheless, this group of municipalities is much more stable. According to Tab. 5, the share of such as municipalities varies around $46.5 \%$ since 2012 onwards. Hence, one can suggest the localisation of a municipality in an FUA is a consequential stimulus contributing to a decision-making of local governments when they opt for higher property taxation.

Tab. 5: Municipalities within FUAs that apply the higher local coefficient policy in 2009-2019

\begin{tabular}{llllllllllll}
\hline & 2009 & 2010 & 2011 & 2012 & 2013 & 2014 & 2015 & 2016 & 2017 & 2018 & 2019 \\
\hline FUA mun. LC & 156 & 143 & 142 & 189 & 229 & 242 & 242 & 262 & 276 & 277 & 280 \\
\hline $\begin{array}{l}\text { FUA mun. LC (\% of } \\
\text { mun. LC) }\end{array}$ & 40.1 & 50.4 & 47.5 & 46.8 & 46.4 & 46.7 & 46.4 & 46.6 & 46.9 & 46.3 & 46.7 \\
\hline
\end{tabular}

FUA mun. LC = municipalities applying higher local coefficient of property tax that are located in FUA

Source: own calculations

On the contrary to the preceding analysis taking into account the industrial infrastructure as notable points in the administrative district of a local government, an FUA is composed of the administrative districts in the neighbourhood of a grand city, such as the capital and the seats of regional governments. The FUAs are a continuous areas, instead of irregularly distributed industrial facilities in space; therefore, the effect of tax mimicking should be more obvious between the FUA members. There are 14 FUAs in the Czech Republic and many tax mimicking municipalities belong to some FUA, as presented in Fig. 1. However, the share of such municipalities is stable since 2012, in spite of a significant rise by leaps and bounds from 189 to 280 municipalities opting for high property taxation. 
Fig. 1: Municipalities with increased local coefficient and FUAs in 2019 core of the FUA = the densely inhabited city whose labour market is highly integrated with the commuting zone within the borders of FUA

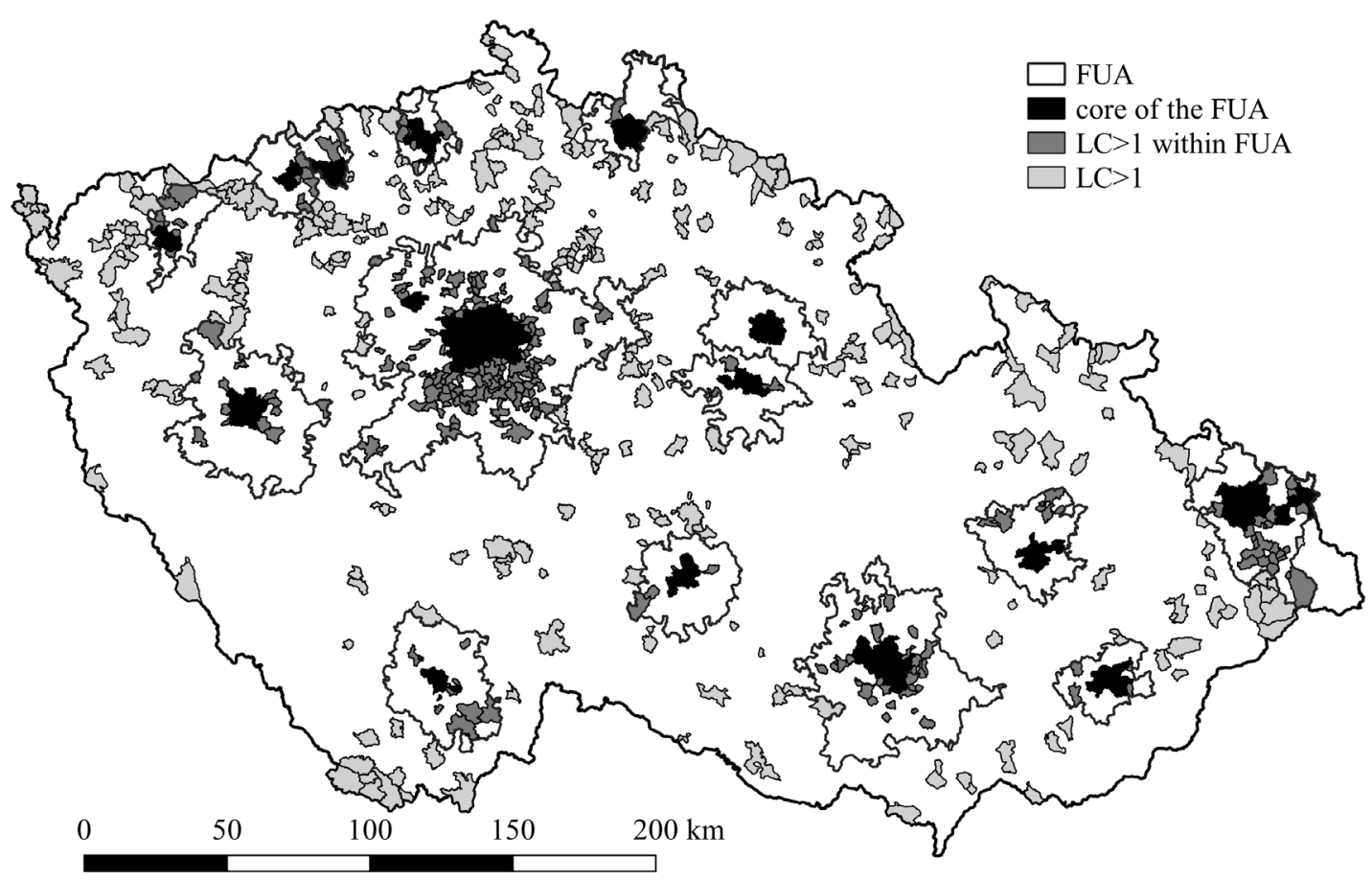

Source: own processing

As presented in the Fig. 1, the number of local governments preferring high property taxation in a FUA varied. There is a chain of municipalities located close to the north-western border to Germany that promote the policy of the higher local property tax coefficient. Those four FUAs are located in the commuting zone determined by the axis Usti nad Labem-Most-Chomutov-Karlovy Vary. Despite the tiny size of these FUAs, they are distinctive by a significant share of municipalities preferring the policy of higher local property tax coefficient. The share varied between 30 (Most) and 35\% (Usti nad Labem). However, the MC within particular FUAs comes from to 70 (Karlovy Vary) to $100 \%$ (Chomutov and Most).

The largest FUA sprawls around the capital (Praha). Although the share of municipalities applying the higher local property tax coefficient policy is ca $26 \%$, the MC is $87 \%$. The policy is often applied in the southern area of the FUA. The Ostrava FUA in the far-eastern tip of the Czech Republic is similar to the FUA of Praha, that is, 25\% local governments opt for the high taxation policy and 95\% tax mimickers. In fact, the FUAs of Praha, Ostrava, Usti nad Labem, Chomutov, Most and Karlovy Vary consists of 208 from 599 municipalities (or 280 integrated in FUAs, respectively) that adopted this policy in the Czech Republic.

In other FUAs, the shares of municipalities that apply higher property tax policy are much lower, as a rule; at the bottom, there are FUAs of Hradec Kralove, Pardubice and Olomouc, which counts only between 3 and 4\% of appliers. As a result, the MCs are also much lower in these FUAs.

Also, we found another interesting and substantial spatial phenomenon about FUA. In some FUAs, the increasing of LC is mostly applied in the nearest commuting zone around the centre of the FUA, for example, Praha, Brno, Ostrava, Plzen or Usti nad Labem, while in the FUA of Olomouc, Jihlava or Ceske Budejovice, the coefficient is rather applied at the outer borders of FUA. Hence, there are probably different patterns of tax mimicking in the Czech Republic, and this phenomenon should be analysed by further research. 


\section{The causality patterns}

As already presented, both the localisation of industry in a municipality as well as the localisation of municipality in a FUA must be considered as important stimuli for any increasing of the LC decided by local governments. In fact, there are more than two-thirds of municipalities with increased LC, wherein we identified one or both factors (industry and FUA), as it implies from Tab. 6.

Tab. 6: Municipalities with one or both factors (industry and FUA) that apply the policy of higher local coefficient in 2009-2019

\begin{tabular}{llllllllllll}
\hline & $\mathbf{2 0 0 9}$ & $\mathbf{2 0 1 0}$ & $\mathbf{2 0 1 1}$ & $\mathbf{2 0 1 2}$ & $\mathbf{2 0 1 3}$ & $\mathbf{2 0 1 4}$ & $\mathbf{2 0 1 5}$ & $\mathbf{2 0 1 6}$ & $\mathbf{2 0 1 7}$ & $\mathbf{2 0 1 8}$ & $\mathbf{2 0 1 9}$ \\
\hline IFU mun. LC & 263 & 211 & 217 & 289 & 342 & 358 & 359 & 389 & 405 & 409 & 411 \\
\hline IFU mun. LC (\% of mun. LC) & 67.6 & 74.3 & 72.6 & 71.5 & 69.2 & 69.1 & 68.8 & 69.2 & 68.9 & 68.4 & 68.6 \\
\hline
\end{tabular}

IFU mun. LC= union of Ind. mun. LC and FUA mun. LC (see Tab. 3 and Tab. 5), i.e. municipalities applying higher local coefficient of property tax that have large industrial facility in their area of administration and/or that are located in FUAs

Source: own calculations

As shown in Tab. 6, the share of municipalities with one or both factors affecting the decision-making of the grade of the local property tax coefficient is quite stable since 2013. That finding is in line with the findings presented in previous part of this study. Nonetheless, the simple tax mimicking behaviour is also an important phenomenon. As already presented in Tab. 2, almost threequarters of municipalities with higher LC were affected by it. Hence, we will proceed an additional method to validate the findings of basic statistics. In particular, we decided to apply the econometrical analysis of Granger causality, which can reveal the links between all three stimuli.

At this point, two facts have to be remind. Firstly, the Granger causation does not mean the unambiguous causation between two variables. It refers to the relationship in which the development of one variable can be better explained by the time-lagged development of other variable than development of its own. Secondly, the results of this procedure are limited, as the volumes we can test are not long enough. Still, the results obtained through this method can help us to understand the possible links and impacts of the property taxation policy.

The results of causality testing summarised in Tab. 7 suggest that there are substantial links among the stimuli under examination. In particular, there is a two-way causation between the large industrial facilities and FUAs. This result is to interpret the existence of cumulative effects of both stimuli that push the municipalities with large industrial facilities located within an FUA to increase the LC of property tax.

The analysis also suggests causation between tax mimicking and increasing of LC in the FUAs. In fact, the mimicking behaviour pushes the municipalities located in the FUAs to increase the LC. On the other hand, the process of increasing the LCs in the FUAs is not intense enough to impact the overall mimicking behaviour significantly. Those results not only validate the previous conclusion about the importance of mimicking in the FUAs, but they confirm also that the tax mimicking is potent behind the borders of FUAs. The analysis suggests causation between tax mimicking and increasing of LC in the FUAs. In fact, the mimicking behaviour pushes the municipalities located in the FUAs to increase the LC. On the other hand, the process of increasing the LCs in the FUAs is not intense enough to impact the overall mimicking behaviour significantly. Those results not only validate the previous conclusion about the importance of mimicking in the FUAs, but they confirm also that the tax mimicking is potent behind the borders of FUAs.

Finally, we found no causation relationships between the tax mimicking and the large industrial facilities in both directions. Similarly, one can consider the process of tax mimicking is not impacted significantly by localisation of industry and vice versa, as mimicking happens in other areas as well. In fact, the large industrial facilities are not strong enough to impact the overall mimicking behaviour significantly. Hence, we can assume that tax mimicking is an independent process that contributes significantly to enlarging the areas of higher property taxation in functional areas of large urban centres. 
Tab. 7: Results of Granger causality testing

\begin{tabular}{lll}
\hline Null hypothesis & F-statistic & Probability \\
\hline Large industrial facilities do not Granger cause the increase of LC in municipalities within FUAs & 16.293 & $0.010^{* *}$ \\
\hline FUAs do not Granger cause the increase of LC in municipalities with large industrial facilities & 9.1567 & $0.029^{* *}$ \\
\hline Mimicking behaviour do not Granger cause the increase of LC in municipalities within FUAs & 5.7500 & $0.062^{*}$ \\
\hline FUAs do not Granger cause the mimicking behaviour & 0.7862 & 0.416 \\
\hline $\begin{array}{l}\text { Mimicking behaviour do not Granger cause the increase of LC in municipalities with large } \\
\text { industrial facilities }\end{array}$ & 0.0299 & 0.869 \\
\hline Large industrial facilities do not Granger cause the mimicking behaviour & 1.3851 & 0.292 \\
\hline
\end{tabular}

* rejection at the $0.10 \ldots ; * * . .0 .05$ level of significance

Source: own calculations

\section{CONCLUSION}

This paper sought to determine factors supporting the continuing of the policy of the high local property tax coefficient in the Czech Republic. The literature review shows that there is large literature about the mimicking phenomenon at the local level of government, but there is not enough literature about the original stimuli for the policy of higher property taxation. Following the findings of Zdražil and Pernica (2018), we examined the assumptions of links between the higher property taxes policy with the demographic and economic booming areas. In particular, two hypotheses were tested: H1: The localisation of industry stimulates municipalities to increase the local property tax. H2: The concentration of population and economic activity stimulates municipalities to increase the local property tax.

We employed the statistical and spatial data of 6,258 municipalities in the Czech Republic between 2009 and 2019 as an analysis input. The analysis focused on the large industrial facilities and functional urban areas of large cities (FUA), as the opportunities for the policy of higher local property taxation. However, it also takes the mimicking phenomenon into account, as the preliminary analysis showed its impacts on raising the property taxes by neighbouring municipalities. Then, the econometrical causal analysis proceeds to explore the links between all three factors under examination.

The analysis concludes that the municipalities burdened by large industrial facilities apply the policy of higher property taxation twice frequently than the rest. On the other hand, the industrial stimuli keep enfeebling after 2010. We also found that increased portion of property tax is a substitutional source of the municipality budged revenues. For instance, it reaches up to tens of per cent for municipalities with large industrial facilities. Similarly, the municipalities in the FUAs apply the policy of higher local property tax coefficient twice frequently than the rest, still this group of municipalities shows stable development. On the other hand, the number of local governments preferring high property taxation is variegated across different FUAs. The unambiguous preference for higher taxation is obvious in a chain of FUAs located close to the north-western border of the Czech Republic and in the largest FUA sprawls around the capital Praha. At last, the causal analysis concludes an existence of cumulative effects of both industry and the FUAs, which push the municipalities with large industrial facilities located within an FUA to increase the local property taxes.

From the mimicking point of view, we found that mimicking policy is an important phenomenon among the municipalities of Czech Republic; however, it has different impacts on both stimuli (industry and FUA). The statistical analysis suggests that it rather incites the municipalities within the FUA to increase the local property taxes. In fact, this result has been also confirmed by the later causal analysis. Besides, we found out that there are different patterns of tax mimicking in the Czech Republic.

With all that in mind, we believe this phenomenon should be analysed by further research to uncover more links and principles. At this point, we suggest searching for more explanations in a settlement structure, in particular, for re-scaling of municipalities into different sizes. As it has been implied by Smith et al. (2011), there are different perceptions of greater or lesser autonomy by municipalities of diverse sizes in the Czech Republic. 


\section{REFERENCES}

Akaike, H. (1974). A new look at the statistical model identification. IEEE Transactions on Automatic Control. 19(6), 716-723.

Allers, M. A., \& Elhorst, J. P. (2005). Tax Mimicking and Yardstick Competition Among Local Governments in the Netherlands. International Tax and Public Finance. 12(4), 493-513 https://doi. org/10.1007/s10797-005-1500-x.

Baskaran, T. (2014). Identifying local tax mimicking with administrative borders and a policy reform. Journal of Public Economics. 118(C), 41-51.

Bastida, F., Benito, B., Guillamón, M. D., \& Ríos, A. M. (2019). Tax mimicking in Spanish municipalities: expenditure spillovers. Yardstick competition or tax competition? Public Sector Economics. 43(2), 115-139.

Besley, T., \& Case, A. (1995). Incumbent behavior: Vote seeking, tax setting and yardstick competition. American Economic Review, 85(1), 25-45.

Bordignon, M., Cerniglia, F., \& Revelli, F. (2003). In search of yardstick competition: a spatial analysis of Italian municipality property tax setting. Journal of Urban Economics. 54(2), 199-217.

Bordignon, M., Cerniglia, F., \& Revelli, F. (2004). Yardstick competition in intergovernmental relationships: theory and empirical predictions. Economic Letters. 83(3), 325-333.

Buettner, T., \& von Schwerin, A. (2016). Yardstick competition and partial coordination: Exploring the empirical distribution of local business tax rates. Journal of Economic Behavior \& Organization. 124, 178-201.

Copernicus Programme. (2020). CORINE Land Cover. [online]. [cit.202001-29]. Available

from https://land.copernicus.eu/pan-european/corine-land-cover.

Dickey, D. A., \& Fuller, W. A. (1979). Distribution of the estimators for autoregressive time series with a unit root. Journal of the American Statistical Association. 74(366), 427-431.

Dubois, E., \& Paty, S. (2010). Yardstick competition: which neighbours matter? The Annals of Regional Science. 44(3), 433-452.

Fossen, F., Mergele, L., \& Pardo, N. (2017). Fueling fiscal interactions: commodity price shocks and local government spending in Colombia. International Tax and Public Finance. 4(4), 616-651.

Gerard, M., Jayet, H., \& Paty, S. (2010). Tax interactions among Belgian municipalities: Do interregional differences matter? Regional Science and Urban Economics. 40(5), 336-342.

Goeminne, S., \& Smolders, C. (2015). Local Tax Rates. Politics and Omitted Variable Bias. Lex Localis. 3(4), 933-951.
Granger, C. (1969). Investigating causal relations by econometric models and cross-spectral methods. Econometrica, 37(3), 424-438.

Granger, C. (1988). Some recent development in a concept of causality. Journal of Econometrics. 39(1-2), 199-211.

Gretl. (2019). Gnu Regression, Econometrics and Time-series Library. [online]. [cit.2019-12-29]. Available from http://gretl.sourceforge.net.

John, P. (1999). Ideas and interests; agendas and implementation: an evolutionary explanation of policy change in British local government finance. The British Journal of Politics and International Relations. 1(1) $39-62$.

Klien, M. (2015). The political side of public utilities: How opportunistic behaviour and yardstick competition shape water prices in Austria. Papers in Regional Science. 94(4), 869-89o.

Latislav, R. (2020). Dolní Morava zvedla daň z nemovitosti na pětinásobek, těží ze ski resortu. [online]. [cit.2020-2-29]. Available from https://www.idnes.cz/pardubice/zpravy/dolni-morava-danz-nemovitosti-pardubicky-kraj-resort-sneznik.A200117_144347_ pardubice-zpravy_lati.

Małkowska, A., Telega, A., Głuszak, M., \& Marona, B. (2018). Spatial interdependence in property taxation: the case of Polish municipalities. Equilibrium. 13(2), 265-283.

MFCR - Ministry of Finance of The Czech Republic. (2020). Monitor an information portal of the Ministry of Finance of The Czech Republic. [online]. [cit.2020-2-21]. Available from https://monitor.statnipokladna. CZ.

OECD. (2012). Redefining "Urban": A New Way to Measure Metropolitan Areas. [online]. [cit.2020-1-15]. Available from https://www.oecdilibrary.org/urban-rural-and-regional-development/redefiningurban_9789264174108-en.

OECD. (2020). FUA list. [online]. [cit.2020-1-10]. Available from https:// www.oecd.org/cfe/regional-policy/functionalurbanareasbycountry.htm.

Ollé Solé, A. (2003). Electoral accountability and tax mimicking: the effects of electoral margins coalition government and ideology. European Journal of Political Economy, 19(4), 685-713.

Otta, E. (2009). Nejvyšší daň schválili v Temelíně. [online]. [cit.2020-125]. Available from https://ceskobudejovicky.denik.cz/zpravy_region/ nejvyssi-dan-schvalili-v-temeline20091229.html.

QGIS. (2019). QGIS project. [online]. [cit.2019-12-25]. Available from https://www.qgis.org/en/site.

Revelli, F., \& Tovmo, P. (2007) Revealed yardstick competition: Local government efficiency patterns in Norway. Journal of Urban Economics. $62(1), 121-134$. 
Said, S. E., \& Dickey, D. A. (1984). Testing for Unit Roots in AutoregressiveMoving Average Models of Unknown Order. Biometrika, 71(3), 599-607.

Sedmihradská, L. (2013). Yardstick Competition in Case of the Czech

Property Tax. Review of Economic Perspectives. 13(2), 77-91.

Sedmihradská, L., \& Bakoš, E. (2015). Who Applies the Real Estate Tax`s Local Coefficient? In: Proceedings of the 2oth International Conference Theoretical and Practical Aspects of Public Finance 2015. Praha: Oeconomica.

Schneider, M. (1987). Local Budgets and the Maximization of Local Property Wealth in the System of Suburban Government. The Journal of Politics. 49(4), 1104-1116.

Smith, S., Bryson, P., \& Cornia, G. (2011). The view from city hall: Local perceptions of intergovernmental fiscal relations in the Czech Republic. Communist and Post-Communist Studies. 44(1), 99-110.

Sokolow, A. (1998). The Changing Property Tax and State-Local Relations. Publius: The Journal of Federalism. 28(1), 165-187.

Zdražil, P., \& Pernica, B. (2018). Property Tax and Quality of Life in the Czech Municipalities: Does the Policy of Raising Local Coefficient Imply Potential or Risk for Development? Review of Economic Perspectives. 18(2), $123-136$. 